\title{
Możliwości zastosowania nanotlenku glinu w zaczynach cementowych przeznaczonych do uszczelniania rur okładzinowych w otworach wiertniczych
}

\section{The possibility of using of nano aluminum oxide in cement slurries for sealing casing in boreholes}

\author{
Marcin Rzepka, Miłosz Kędzierski \\ Instytut Nafty i Gazu - Państwowy Instytut Badawczy
}

\begin{abstract}
STRESZCZENIE: W artykule zamieszczono składy i wyniki badań receptur zaczynów cementowych zawierających od 1\% do 5\% nanotlenku glinu $\left(\mathrm{n}-\mathrm{Al}_{2} \mathrm{O}_{3}\right)$ przeznaczonych do uszczelniania kolumn rur okładzinowych w otworach wiertniczych o temperaturach dynamicznych około $30^{\circ} \mathrm{C}$ oraz około $60^{\circ} \mathrm{C}$. Receptury cementowe opracowane zostały w INiG - PIB w Laboratorium Zaczynów Uszczelniających. Zaczyny posiadały gęstość od około $1820 \mathrm{~kg} / \mathrm{m}^{3}$ do około $1920 \mathrm{~kg} / \mathrm{m}^{3}$, a ich sporządzanie odbywało się na bazie cementu portlandzkiego CEM I 42,5 oraz wiertniczego klasy G. Czasy wiązania oraz gęstnienia zaczynów dobierane były odpowiednio do danych warunków geologiczno-technicznych. W przypadku zaczynów badanych w niższej temperaturze zwracano szczególną uwagę na proces żelowania i wiązania receptur. Parametry te odgrywają bowiem kluczową rolę w ograniczaniu ewentualnych migracji gazowych z płytkich horyzontów produktywnych. Starano się zatem tak je dobierać, aby proces żelowania i wiązania receptur przebiegał w odpowiednio krótkim czasie. Z kolei w wyższych temperaturach skupiano się na opracowaniu receptur o podwyższonej wytrzymałości mechanicznej, a co za tym idzie - szczelnej i zbitej mikrostrukturze. Opracowano receptury o bardzo dobrych parametrach technologicznych, które po utwardzaniu (po 28 dniach hydratacji) posiadały bardzo wysokie wartości wytrzymałości na ściskanie, dochodzące nawet do $40 \mathrm{MPa}$. Tak wysokie wartości wytrzymałości są niezwykle trudne do uzyskania w przypadku zastosowania zaczynów konwencjonalnych. Potwierdzeniem wyjątkowo trwałej mikrostruktury próbek zawierających n- $\mathrm{Al}_{2} \mathrm{O}_{3}$ są również fotografie próbek zaczynów wykonane za pomocą mikroskopii skaningowej. Obok fotografii bazowych kamieni cementowych, na których widać pory, przedstawiono obrazy mikroskopowe próbek z dodatkiem $3 \% \mathrm{n}-\mathrm{Al}_{2} \mathrm{O}_{3}$, na których obserwujemy zbitą matrycę cementową, cechującą się bardzo małą przepuszczalnością. Ponadto próbki kamieni cementowych uzyskane z zaczynów z n- $\mathrm{Al}_{2} \mathrm{O}_{3}$ charakteryzowały się bardzo niską zawartością porów kapilarnych. Zdecydowaną większość ogólnej ilości porów stanowiły pory o najmniejszych rozmiarach (poniżej $100 \mathrm{~nm}$ ). Poprawa szczelności matrycy cementowej poprzez zredukowanie do wartości około 1,5\% porów mogących transportować medium złożowe sprawia, że receptury zaczynów cementowych zawierających dodatek nanotlenku glinu mogą być z powodzeniem używane podczas uszczelniania kolumn rur okładzinowych w otworach wiertniczych wykonywanych na złożach węglowodorów.
\end{abstract}

Słowa kluczowe: nanotlenek glinu $\left(\mathrm{n}-\mathrm{Al}_{2} \mathrm{O}_{3}\right)$, zaczyn cementowy, kamień cementowy, wiązanie zaczynu, wytrzymałość mechaniczna.

ABSTRACT: The article presents compositions and test results for cement slurries formulations containing from $1 \%$ to $5 \%$ of nano aluminum oxide $\left(\mathrm{n}-\mathrm{Al}_{2} \mathrm{O}_{3}\right)$ for sealing the casing columns in boreholes with dynamic temperatures of about $30^{\circ} \mathrm{C}$ and $60^{\circ} \mathrm{C}$. Laboratory tests of cement slurries were carried out at Oil and Gas Institute - National Research Institute. The densities of tested slurries ranged from 1,820 to $1,920 \mathrm{~kg} / \mathrm{m}^{3}$, and were prepared on the basis of Portland cement CEM I 42,5 and class G oil well cement. Cement slurries had thickening times properly matched to given geological and technical conditions. For slurries tested at lower temperatures, particular attention was paid to the gelling and setting process of cement slurries. These parameters play a key role in limiting possible gas migrations from shallow gas accumulations. They were selected so that the gelling and setting process could be carried out in a sufficiently short time. At higher temperatures, the focus was on developing cement slurry formulations with increased mechanical strength and a tight and compact microstructure. Cement slurry formulations with very good technological parameters were developed, which after curing (after 28 days of hydration) had very high values of compressive strength, reaching up to $40 \mathrm{MPa}$. Such high compressive strength values are extremely difficult to obtain with conventional cement slurries. Scanning electron microscope images of cement samples also confirm extremely compact microstructure of the samples with nano- $\mathrm{SiO}_{2}$. In addition to the photographs of base cement stones, which

Autor do korespondencji: M. Rzepka, e-mail: marcin.rzepka@inig.pl

Artykuł nadesłano do Redakcji: 16.10.2019 r. Zatwierdzono do druku: 31.12.2019 r. 
show pores, microscopic images of samples with the addition of $3 \% \mathrm{n}-\mathrm{Al}_{2} \mathrm{O}_{3}$ are presented, where we observe a compact cement matrix with very low permeability. Furthermore, samples containing $n-\mathrm{Al}_{2} \mathrm{O}_{3}$ were characterized by a very low content of capillary pores. Pores of the smallest size (below $100 \mathrm{~nm}$ ) constituted the vast majority of the total number of pores. Improvement of cement matrix tightness by reducing the amount of pores that can transport the reservoir medium to approx. $1.5 \%$ means that cement slurry formulas containing nano aluminum oxide can be successfully used in the process of cementing casing strings in boreholes.

Key words: nano aluminum oxide $\left(\mathrm{n}-\mathrm{Al}_{2} \mathrm{O}_{3}\right)$, cement slurry, cement sheath, cement setting, mechanical strength.

\section{Wprowadzenie}

Obecnie w różnych gałęziach przemysłu następuje szybki rozwój nanotechnologii, której wytworem są m.in. cząstki, włókna, warstwy itp. mające przynajmniej jeden wymiar mniejszy od $100 \mathrm{~nm}$ oraz nanomateriały, czyli układy składające się z nanoobiektów. Innowacyjność nanotechnologii polega na tym, że morfologia i rozmiar poszczególnych elementów nanostruktury może mieć większy wpływ na właściwości materiału (substancji) niż jej skład chemiczny. Nowe właściwości ujawniają się po przekroczeniu krytycznej wielkości ziarna, co nazywane jest efektem nanoskali. Konwersja substancji do nanoskali wiąże się ze zmianą jej właściwości, tj.: wytrzymałości mechanicznej, odporności termicznej, przewodności cieplnej, zdolności do gromadzenia ładunku elektrycznego, aktywności biologicznej itp.

Według opinii naukowców przemysł cementowy jest klasyfikowany w pierwszej dziesiątce potencjalnych beneficjentów rozwoju nanotechnologii w najbliższym czasie. Ogólnie w literaturze cement modyfikowany nanocząstkami określany jest mianem nanocementu. Do najczęściej stosowanych nanoproduktów w technologii cementu należy nanokrzemionka oraz nanometryczny dwutlenek tytanu $\mathrm{TiO}_{2}$. Dużo prac badawczych prowadzi się w zakresie wykorzystania w kompozytach cementowych nanomateriałów węglowych, głównie nanorurek i grafenu. Ostatnio pojawiły się prace nad zastosowaniem w technologii cementowej nanotlenku glinu n- $\mathrm{Al}_{2} \mathrm{O}_{3}$.

Rozwój technologii cementu na przestrzeni ostatnich lat prowadzony był głównie na drodze wykorzystywania coraz drobniejszych materiałów (Patil i Deshpande, 2012). Poszczególne etapy wytwarzania cementu polegały na ograniczeniu wielkości ziaren stosowanych składników, np. średnica ziarna zmielonego piasku wynosi około $0,04-0,05 \mathrm{~mm}, \mathrm{tj}$. około 40 000-50 $000 \mathrm{~nm}$, pyłu krzemionkowego (mikrokrzemionki) $-150-200 \mathrm{~nm}$, natomiast nanokrzemionki czy nanogli$\mathrm{nu}$ - około 20-30 $\mathrm{nm}$. Zastosowanie zatem nanokrzemionki czy nanoglinu w składzie zaczynu cementowego było kolejnym krokiem milowym w rozwoju technologicznym tej gałęzi przemysłu (De La Roij et al., 2012; Dębińska, 2014, 2015; Dębińska i Rzepka, 2016). Nanocząsteczki (zarówno n- $\mathrm{SiO}_{2}$, jak i n- $\mathrm{Al}_{2} \mathrm{O}_{3}$ ) wypełniają puste przestrzenie między ziarnami cementu, w wyniku czego następuje zamknięcie kanałów porowych (Li et al., 2004; Li et al. 2006; Nazari i Riahi, 2011). Dobrze zdyspergowane nanocząsteczki powodują przyspieszenie hydratacji zaczynu cementowego i sprzyjają tworzeniu się niewielkich kryształów oraz małych jednorodnych skupisk fazy C-S-H. Poza tym nanocząstki uczestniczą w reakcjach pucolanowych lub je przyspieszają, co powoduje zużywanie się $\mathrm{w}$ twardniejącym cemencie nietrwałego chemicznie portlandytu $\mathrm{Ca}(\mathrm{OH})_{2}$ i tworzenie się „dodatkowego” żelu fazy C-S-H, budującego szkielet matrycy cementowej (Nazari i Riahi, 2011). Poza tym nanocząstki poprawiają strukturę kontaktu na styku ziaren cementowych, co skutkuje mocniejszym związaniem oraz zmniejszeniem ilości ewentualnych pęknięć.

\section{Możliwości zastosowania nanotlenku glinu do sporządzania zaczynów cementowych}

W literaturze światowej po roku 2010 opublikowano dość znaczną liczbę artykułów naukowych, w których opisano możliwości wykorzystania różnego rodzaju nanomateriałów w przemyśle naftowym i wydobywczym (Patil i Deshpande, 2012; Santra et al. 2012; Wilk et al., 2014; Uliasz et al., 2015; Hadi i Ameer, 2017; Leon et al., 2019).

Jeśli chodzi o stosowanie nanocząsteczek w kompozycjach mieszanek cementowych, to należy tu wymienić m.in.: - ditlenek krzemionki (powszechne znany pod nazwą nanokrzemionka: $\left.\mathrm{n}-\mathrm{SiO}_{2}\right)$;

- ditlenek tytanu (nanotlenek tytanu n- $-\mathrm{TiO}_{2}$ );

- nanotlenek cynku (n-ZnO);

- nanostruktury węglowe: nanorurki, grafen, fulereny.

Ostatnio pojawiły się publikacje dotyczące możliwości zastosowania $\mathrm{w}$ recepturach cementowych nanotlenku glinu (n- $\mathrm{Al}_{2} \mathrm{O}_{3}$ ). Autorzy (Hadi i Ameer, 2017) po przeprowadzaniu analiz laboratoryjnych podkreślali wysokie zalety takich zaczynów, zwracając szczególnie uwagę na poprawę wytrzymałości mechanicznej. Zauważyli także, że cząsteczki nanoglinu nie wpływały w znaczący sposób na gęstość zaczynów, a po dodaniu do receptury cementowej powodowały przyspieszenie jej czasu wiązania. Po zastosowaniu nanoglinu zaobserwowali również wzrost lepkości i granicy płynięcia zaczynu, a także obniżenie odstoju wody w zaczynie (co jest szczególną zaletą przy uszczelnianiu otworów naftowych). W badaniach 

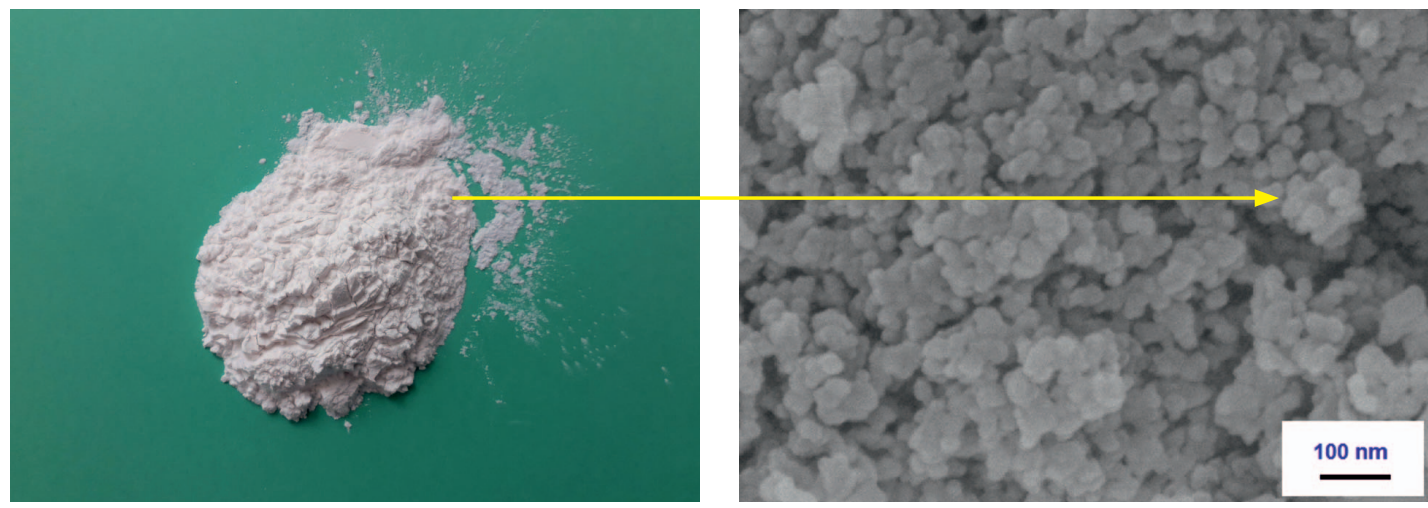

Rys. 1a i 1b. Po lewej nanotlenek glinu ( $\mathrm{n}-\mathrm{Al}_{2} \mathrm{O}_{3}$ ) o średnicy ziaren około 20-30 nm (w postaci proszku) używany w badaniach laboratoryjnych. Po prawej mikrostruktura tegoż nanotlenku glinu (zdjęcie wykonane pod mikroskopem skaningowym). Strzałką zaznaczono pojedynczą cząsteczkę n- $\mathrm{Al}_{2} \mathrm{O}_{3}$

Fig. 1a. and 1b. On the left, nanoaluminum oxide $\left(\mathrm{n}-\mathrm{Al}_{2} \mathrm{O}_{3}\right)$ with a grain diameter of approx. 20-30 nm (in the form of powder) used in laboratory tests. On the right, the microstructure of this nanoaluminum oxide (SEM image). A single $\mathrm{n}-\mathrm{Al}_{2} \mathrm{O}_{3}$ molecule is marked with an arrow

wykonywanych przez wymienionych autorów prowadzono głównie testy w warunkach określanych przez normę API, nie uwzględniając wprowadzenia dodatków i domieszek koniecznych do wykonania odpowiedniej receptury cementowej.

W niniejszym artykule podjęto badania nad możliwościami użycia zaczynów z dodatkiem nanotlenku glinu do uszczelniania otworów wiertniczych wykonywanych dla potrzeb przemysłu naftowego. Do zaczynów cementowych dodawano szereg dodatków stosowanych przy sporządzaniu receptur na wiertni, tj. odpieniacze, upłynniacze, środki antyfiltracyjne czy regulatory czasu wiązania. W testowanych zaczynach cementowych jako spoiwo wiążące zastosowano cement portlandzki CEM I 42,5 (dla temperatury $30^{\circ} \mathrm{C}$ ) oraz wiertniczy klasy „G” (dla temperatury $60^{\circ} \mathrm{C}$ ). Nanokomponent $\left(\mathrm{n}-\mathrm{Al}_{2} \mathrm{O}_{3}\right)$ dodawano do wody zarobowej i dyspergowano przy użyciu sonifikatora Sonics VC 505 (stosując czas ujednorodniania 5 minut). $\mathrm{W}$ badaniach używano nano- $\mathrm{Al}_{2} \mathrm{O}_{3} \mathrm{w}$ proszku Aluminum Oxide Nanopowder $\left(\mathrm{Al}_{2} \mathrm{O}_{3}\right.$, średnica $99 \%$ jego cząsteczek wynosi około 20-30 nm). Na rysunkach 1 a i $1 \mathrm{~b}$ przedstawiono nanotlenek glinu $\left(\mathrm{n}-\mathrm{Al}_{2} \mathrm{O}_{3}\right)$ wykorzystywany podczas badań oraz jego strukturę - ziarna o średnicy około 20-30 nm.

\section{Badania laboratoryjne zaczynów i kamieni cementowych $z$ dodatkiem nanotlenku glinu}

Testy laboratoryjne na zaczynach cementowych zawierających dodatek $\mathrm{n}-\mathrm{Al}_{2} \mathrm{O}_{3}$ prowadzone były w Laboratorium Zaczynów Uszczelniających INiG - PIB zgodnie z normami: Przemyst naftowy i gazowniczy - Cementy i materiaty do cementowania otworów - Część 1: Specyfikacja (PN-EN ISO 10426-1:2009) oraz Przemyst naftowy i gazowniczy - Cementy i materiały do cementowania otworów wiertniczych-Częśc 2: Badania cementów wiertniczych (PN-EN ISO 10426-2:2003).
W badanych zaczynach cementowych jako spoiwo wiążące zastosowano cement portlandzki CEM I 42,5 (dla temperatury $30^{\circ} \mathrm{C}$ ) oraz wiertniczy klasy „G” (dla temperatury $60^{\circ} \mathrm{C}$ ). Użycie takich rodzajów cementów było podyktowane uwarunkowaniami panującymi w otworach wiertniczych oraz doświadczeniem posiadanym przez INiG - PIB (Rzepka et al., 2019; Rzepka i Kędzierski, 2019), który współpracuje z krajowymi serwisami cementacyjnymi, wykonującymi zabiegi cementowania.

Podczas prowadzenia testów koncentrowano się na opracowaniu receptur przeznaczonych do uszczelniania kolumn rur okładzinowych w otworach wiertniczych zlokalizowanych w najbardziej perspektywicznych obszarach naszego kraju. Otwory te wiercone są z reguły do głębokości od kilkuset do około 1500-2500 metrów w zależności od prognozowanych głębokości zalegania warstw produktywnych. W przypadku płytszych otworów (gdzie często istnieje ryzyko wystąpienia migracji gazowych) w badaniach laboratoryjnych przyjęto temperaturę denną wynoszącą $30^{\circ} \mathrm{C}$ oraz ciśnienie $10 \mathrm{MPa}$, natomiast w przypadku otworów głębszych (gdzie koncentrowano się głównie na wytrzymałości płaszcza cementowego) - temperaturę $60^{\circ} \mathrm{C}$ i ciśnienie $25 \mathrm{MPa}$. Wstępne badania $\mathrm{z}$ nanotlenkiem glinu były ukierunkowane na odpowiedni dobór współczynnika wodno-cementowego (w/c) oraz ilości dodawanych nanokomponentów. Po wykonaniu próbnych analiz stwierdzono, że najkorzystniejsze rezultaty uzyskuje się, stosując współczynniki w/c na poziomie: 0,50 (w przypadku zaczynów na bazie cementu portlandzkiego CEM I 42,5) oraz 0,44 (dla zaczynów na bazie cementu wiertniczego klasy „G”).

Tabela 1 przedstawia składy sześciu zaczynów cementowych testowanych w temperaturze $30^{\circ} \mathrm{C}$. Zamieszczono tam składy bazowe (zaczyn A oraz D), tj. bez dodatku n- $\mathrm{Al}_{2} \mathrm{O}_{3}$, oraz receptury zawierające $1 \% \mathrm{n}-\mathrm{Al}_{2} \mathrm{O}_{3}$ (zaczyn $\mathrm{B}$ oraz $\mathrm{E}$ ) oraz $3 \% \mathrm{n}-\mathrm{Al}_{2} \mathrm{O}_{3}$ (zaczyn C oraz F). Zaczyny A, B oraz C zawierały $1 \%$ dodatku przyspieszającego wiązanie, natomiast 
zaczyny D, E oraz F - 0,5\% tego dodatku. W badaniach skupiono się głównie na najważniejszych z punktu widzenia zapobiegania migracji gazu pomiarach, $\mathrm{tj}$. określeniu odpowiednio krótkiego czasu przejścia transition time - TT (czyli czasu, w którym statyczna wytrzymałość strukturalna SGS z wartości 50 Pa wzrośnie do wartość $250 \mathrm{~Pa}$ ) oraz na szybkim procesie wiązania i przejściu zaczynu w fazę stałą. Z literatury wiadomo, że w płytkich otworach wiertniczych krótki czas przejścia TT oraz szybkie wiązanie zaczynu ogranicza ryzyko powstania ekshalacji gazowych.

W tabeli 2 zamieszczono wyniki badań zaczynów i kamieni cementowych A, B, C, D, E i F. Zaczyny cementowe posiadały gęstości w zakresie $1820-1830 \mathrm{~kg} / \mathrm{m}^{3}$. W zaczynach bazowych (bez dodatku nanocząsteczek) odstój wody wynosił 0,5\%. Zaczyny zawierające $1 \%$ oraz $3 \% \mathrm{n}-\mathrm{Al}_{2} \mathrm{O}_{3}$ cechowały się zerowym odstojem wody. Lepkość plastyczna zaczynów wzrastała wraz ze wzrostem ilości n- $\mathrm{Al}_{2} \mathrm{O}_{3} \mathrm{i}$ wynosiła: dla zaczynów bazowych - około $125 \mathrm{mPa} \cdot \mathrm{s}$, a dla zaczynów zawierających $3 \% \mathrm{n}-\mathrm{Al}_{2} \mathrm{O}_{3}-$ około $150 \mathrm{mPa} \cdot \mathrm{s}$, co jest wartością dość wysoką. Podobna sytuacja występowała w przypadku granicy płynięcia (jej wartość również rosła wraz ze wzrostem ilości nanotlenku glinu w zaczynie i dla 3\% n- $\mathrm{Al}_{2} \mathrm{O}_{3}$ wynosiła około $20 \mathrm{~Pa}$ ). Prowadząc testy zaczynów na ultrasonograficznym analizatorze cementu UCA z modułem do badania żeli SGSM, zaobserwowano wyraźny efekt skrócenia czasu żelowania zaczynów wraz ze wzrostem ilości n- $\mathrm{Al}_{2} \mathrm{O}_{3}$. Zaczyn bazowy oznaczony symbolem A uzyskał czas przejścia TT (transition time) wynoszący 46 minut. Po wprowadzeniu $1 \% \mathrm{n}-\mathrm{Al}_{2} \mathrm{O}_{3}$ w zaczynie B czas przejścia TT uległ skróceniu do 20 minut. Dalsze zwiększenie $\mathrm{n}-\mathrm{Al}_{2} \mathrm{O}_{3}$ do $3 \% \mathrm{w}$ zaczynie $\mathrm{C}$ spowodowało kolejne skracania czasu przejścia (zaczyn ten osiągnął TT zaledwie po 9 minutach, co może być niebezpieczne z uwagi na efekt zbyt szybkiego żelowania). Przykładowe wyniki uzyskane z analizatora SGSM dla zaczynów A, B oraz C (tj. bez udziału nanocząsteczek oraz $\mathrm{z}$ dodatkiem $1 \%$ i $3 \% \mathrm{n}-\mathrm{Al}_{2} \mathrm{O}_{3}$ ) zamieszczono na rysunkach od 2 do 4 . Podobne rezultaty otrzymano dla tych samych zestawów zaczynów zawierających zmniejszoną ilość przyspieszacza wiązania. Zaczyny te (z uwagi na mniejsze ilości dodatku przyspieszającego) żelowały nieco wolniej. Mianowicie zaczyn bazowy D uzyskał czas przejścia TT wynoszący 58 minut, zaczyn $\mathrm{E} \mathrm{z} 1 \% \mathrm{n}-\mathrm{Al}_{2} \mathrm{O}_{3}-28$ minut, natomiast zaczyn F z 3\% n- $\mathrm{Al}_{2} \mathrm{O}_{3}-11$ minut. Analogiczna sytuacja wystąpiła w przypadku testów wiązania, prowadzonych na automatycznym aparacie Vicata. Zaczyny od A do C (zawierające $1 \%$ dodatku przyspieszającego) wraz ze wzrostem koncentracji n- $\mathrm{Al}_{2} \mathrm{O}_{3}$ uzyskiwały coraz to krótsze czasy początku i końca wiązania. Tak samo zachowywały się zaczyny D, E oraz F (zawierające 0,5\% dodatku przyspieszającego), w których wzrost koncentracji $\mathrm{n}-\mathrm{Al}_{2} \mathrm{O}_{3}$ powodował szybsze zachodzenie procesów wiązania. Dla przykładu zaczyn A (bez udziału $\mathrm{n}-\mathrm{Al}_{2} \mathrm{O}_{3}$ ) uzyskał koniec wiązania po 332 minutach, zaczyn $\mathrm{B}\left(\mathrm{z} 1 \% \mathrm{n}-\mathrm{Al}_{2} \mathrm{O}_{3}\right)$ - po czasie 313 minut, natomiast zaczyn $\mathrm{C}$ ( z 3\% n- $\mathrm{Al}_{2} \mathrm{O}_{3}$ ) - już po 273 minutach. Wyniki otrzymane za pomocą aparatu Vicata dla zaczynów A, B oraz $\mathrm{C}$ zamieszczono na rysunkach od 5 do 7 . W temperaturze około $30^{\circ} \mathrm{C}$ można zatem nanotlenkowi glinu $\left(\mathrm{n}-\mathrm{Al}_{2} \mathrm{O}_{3}\right)$ przypisać funkcję skutecznego akceleratora powodującego zarazem wyraźne skracanie czasu żelowania zaczynów. Na rysunku 8 w formie wykresu zamieszczono zmiany wytrzymałości na ściskanie dla próbek A, B, C, D, E oraz F po 2, 7, 14 i 28 dniach hydratacji. Można zauważyć, że wytrzymałości próbek z dodatkiem $1 \%$ i $3 \%$ n- $\mathrm{Al}_{2} \mathrm{O}_{3}$ po 28 dniach hydratacji osiągają wartości około $35 \mathrm{MPa}$, podczas gdy próbki bazowe uzyskują po tym czasie wytrzymałość około $30 \mathrm{MPa}$.

Składy zaczynów cementowych, na których prowadzono badania w temperaturze $60^{\circ} \mathrm{C}$ i pod ciśnieniem $25 \mathrm{MPa}$, zamieszczono w tabeli 3. Badaniom poddano 4 zaczyny cementowe. Były to: zaczyn bazowy, oznaczony w tabelach 3 oraz 4 symbolem $\mathrm{G}$ (bez dodatku nanokomponentów), oraz zaczyny zawierające $1 \%, 3 \%$ oraz $5 \%$ n- $\mathrm{Al}_{2} \mathrm{O}_{3}$ (oznaczone odpowiednio symbolami: $\mathrm{H}, \mathrm{J}$ oraz $\mathrm{K}$ ). Wszystkie testowane zaczyny zawierały m.in. dodatek odpieniający, dodatek upłynniający oraz dodatek opóźniający czas wiązania.

W tabeli 4 zamieszczono wyniki badań uzyskane dla zaczynów i kamieni cementowych badanych w $60^{\circ} \mathrm{C}$. Zaczyn bazowy oznaczony symbolem G posiadał gęstość $1900 \mathrm{~kg} / \mathrm{m}^{3}$. W miarę wzrostu koncentracji nanotlenku glinu obserwowano niewielkie zwiększanie się gęstości. Zaczyn J z 3\% n- $\mathrm{Al}_{2} \mathrm{O}_{3}$ posiadał gęstość $1910 \mathrm{~kg} / \mathrm{m}^{3}$, natomiast zaczyn $\mathrm{K}$ z 5\% $\mathrm{n}-\mathrm{Al}_{2} \mathrm{O}_{3}$ - gęstość $1920 \mathrm{~kg} / \mathrm{m}^{3}$. W zaczynie bazowym zanotowano odstój wody wynoszący $0,3 \%$. Po dodaniu nanotlenku glinu odstój w zaczynach wynosił zero. Podobnie jak w przypadku pomiarów prowadzonych w niższej temperaturze, tak i tutaj wraz ze wzrostem ilości n- $\mathrm{Al}_{2} \mathrm{O}_{3} \mathrm{w}$ zaczynie zaobserwowano wzrost lepkości plastycznej oraz granicy płynięcia. Dla przykładu, zaczyn oznaczony symbolem $\mathrm{G}$, bez dodatku nanotlenku glinu, posiadał lepkość $87 \mathrm{mPa} \cdot \mathrm{s}$ i granicę płynięcia 3,4 $\mathrm{Pa}$, podczas gdy po dodaniu $3 \% \mathrm{n}-\mathrm{Al}_{2} \mathrm{O}_{3}$ (czyli po otrzymaniu zaczynu oznaczonego symbolem J) lepkość wzrosła do $151,5 \mathrm{mPa} \cdot \mathrm{s}$, a granica płynięcia do 5,5 $\mathrm{Pa}$. W temperaturze $60^{\circ} \mathrm{C}$ i pod ciśnieniem $25 \mathrm{MPa}$ badano również czasy gęstnienia, tj. czasy uzyskania przez zaczyny konsystencji $30 \mathrm{Bc}$ i $100 \mathrm{Bc}$. Tu również zaobserwowano skracanie czasów gęstnienia wraz ze wzrostem koncentracji nanotlenku glinu. Optymalnymi parametrami, jeśli chodzi o czas gęstnienia, cechował się zaczyn cementowy oznaczony symbolem J, zawierający $3 \% \mathrm{n}-\mathrm{Al}_{2} \mathrm{O}_{3}$, dla którego uzyskano konsystencję $30 \mathrm{Bc}$ po 2 godzinach 58 minutach oraz $100 \mathrm{Bc}$ po 4 godzinach 3 minutach. Po wykonaniu testów płynnych zaczynów przystąpiono do badania kamieni cementowych. Przykładowe 
wyniki badań narastania wczesnej wytrzymałości uzyskane z ultrasonograficznego analizatora cementu (UCA) dla zaczynu oznaczonego symbolem $\mathrm{J}$, zawierającego $3 \% \mathrm{n}-\mathrm{Al}_{2} \mathrm{O}_{3}$, przedstawiono na rysunku 9. Wyniki testów otrzymane przy użyciu UCA wskazują, że już po 12 godzinach wytrzymałość kamienia cementowego wynosiła około $21 \mathrm{MPa}$, a po 24 godzinach - około $25 \mathrm{MPa}$. W późniejszym okresie następował dalszy wzrost wytrzymałości, do wartości około $31 \mathrm{MPa}$ po 48 godzinach. Wyniki badań wczesnej wytrzymałości dla wszystkich próbek badanych w temperaturze $60^{\circ} \mathrm{C}$ zestawiono w tabeli 4 w ostatnim wierszu. Zaczyny oznaczone symbolami G, H, J oraz K utwardzano także w autoklawie (w temperaturze $60^{\circ} \mathrm{C}$ i pod ciśnieniem $25 \mathrm{MPa}$ ), a następnie wykonywano na nich pomiary wytrzymałości na ściskanie po 7, 14 i 28 dniach deponowania. Na rysunku 10 przedstawiono w sposób graficzny uzyskane wyniki. Jak można zauważyć, najwyższe parametry wytrzymałościowe posiada zaczyn J, zawierający
$3 \%$ n- $\mathrm{Al}_{2} \mathrm{O}_{3}$. Jego wytrzymałość na ściskanie po 28 dniach sięga $40 \mathrm{MPa}$. Należy również zauważyć, że zaczyn K, z większą koncentracją nanotlenku glinu, tj. 5\% n- $\mathrm{Al}_{2} \mathrm{O}_{3}$, charakteryzuje się najniższą wytrzymałością na ściskanie spośród badanych próbek. Można to wytłumaczyć trudnościami w równomiernym rozmieszczeniu się dużych ilości nanocząsteczek w zaczynie i tworzeniem się dużych aglomeratów. Po przekroczeniu pewnej koncentracji nanocząsteczek w roztworze „efekt nanoskali” może zatem przestać działać.

Na uwagę zasługują także niezwykle korzystne paramenty mikrostruktury powstałej z zaczynów cementowych zawierających nanotlenek glinu. W testowanych próbkach udział porów o średnicy powyżej $10000 \mathrm{~nm}$ w całej matrycy kamienia cementowego wynosił zalewie około 1,5-2\%, natomiast udział porów o średnicy poniżej $100 \mathrm{~nm}$ - aż około 96\%. Można zatem powiedzieć, że matryca cementowa zagęszczona przez $\mathrm{n}-\mathrm{Al}_{2} \mathrm{O}_{3}$ jest wyjątkowo szczelna i mało porowata.

Tabela 1. Składy zaczynów cementowych testowanych w temperaturze $30^{\circ} \mathrm{C}$ i pod ciśnieniem $10 \mathrm{MPa}$

Table 1. Compositions of cement slurries tested at $30^{\circ} \mathrm{C}$ and a pressure of $10 \mathrm{MPa}$

\begin{tabular}{|c|c|c|c|c|c|c|}
\hline $\begin{array}{l}\text { Symbol zaczynu, temperatura i ciśnienie / } \\
\text { Składniki w [\%] bwoc }\end{array}$ & $\begin{array}{c}\text { Zaczyn A } \\
\left(30^{\circ} \mathrm{C} / 10 \mathrm{~Pa}\right)\end{array}$ & $\begin{array}{c}\text { Zaczyn B } \\
\left(30^{\circ} \mathrm{C} / 10 \mathrm{~Pa}\right)\end{array}$ & $\begin{array}{c}\text { Zaczyn C } \\
\left(30^{\circ} \mathrm{C} / 10 \mathrm{~Pa}\right)\end{array}$ & $\begin{array}{c}\text { Zaczyn D } \\
\left(30^{\circ} \mathrm{C} / 10 \mathrm{~Pa}\right)\end{array}$ & $\begin{array}{c}\text { Zaczyn E } \\
\left(30^{\circ} \mathrm{C} / 10 \mathrm{~Pa}\right)\end{array}$ & $\begin{array}{c}\text { Zaczyn F } \\
\left(30^{\circ} \mathrm{C} / 10 \mathrm{~Pa}\right)\end{array}$ \\
\hline Współczynnik w/c (woda wodociągowa) & 0,50 & 0,50 & 0,50 & 0,50 & 0,50 & 0,50 \\
\hline Nanotlenek glinu, $\mathbf{n}-\mathrm{Al}_{2} \mathrm{O}_{3}$ & - & 1 & 3 & - & 1 & 3 \\
\hline $\mathrm{KCl}^{* *}$ & 3,0 & 3,0 & 3,0 & 3,0 & 3,0 & 3,0 \\
\hline Dodatek odpieniający & 0,5 & 0,5 & 0,3 & 0,3 & 0,3 & 0,3 \\
\hline Dodatek upłynniający & 0,05 & 0,05 & 0,05 & 0,05 & 0,05 & 0,05 \\
\hline Przyspieszacz czasu wiązania & 1,0 & 1,0 & 1,0 & 0,5 & 0,5 & 0,5 \\
\hline Dodatek spęczniający & 0,3 & 0,3 & 0,3 & 0,3 & 0,3 & 0,3 \\
\hline Mikrocement & 5,0 & 5,0 & 5,0 & 5,0 & 5,0 & 5,0 \\
\hline Cement portlandzki CEM I 42,5 & 100 & 100 & 100 & 100 & 100 & 100 \\
\hline
\end{tabular}

w/c - współczynnik wodno-cementowy

* bwoc - tj. w stosunku do masy suchego cementu

${ }^{* *} \mathrm{KCl}$ dodawany był w stosunku do masy wody zarobowej (bwow)

Tabela 2. Parametry zaczynów i kamieni cementowych testowanych w temperaturze $30^{\circ} \mathrm{C}$ i pod ciśnieniem $10 \mathrm{MPa}$

Table 2. Parameters of cement slurries and sheaths tested at $30^{\circ} \mathrm{C}$ and a pressure of $10 \mathrm{MPa}$

\begin{tabular}{|c|c|c|c|c|c|c|}
\hline $\begin{array}{c}\text { Symbol zaczynu, temperatura i ciśnienie / } \\
\text { Oznaczany parametr }\end{array}$ & $\begin{array}{c}\text { Zaczyn A } \\
\left(30^{\circ} \mathrm{C} / 10 \mathrm{~Pa}\right)\end{array}$ & $\begin{array}{c}\text { Zaczyn B } \\
\left(30^{\circ} \mathrm{C} / 10 \mathrm{~Pa}\right)\end{array}$ & $\begin{array}{c}\text { Zaczyn C } \\
\left(30^{\circ} \mathrm{C} / 10 \mathrm{~Pa}\right)\end{array}$ & $\begin{array}{c}\text { Zaczyn D } \\
\left(30^{\circ} \mathrm{C} / 10 \mathrm{~Pa}\right)\end{array}$ & $\begin{array}{c}\text { Zaczyn E } \\
\left(30^{\circ} \mathrm{C} / 10 \mathrm{~Pa}\right)\end{array}$ & $\begin{array}{c}\text { Zaczyn F } \\
\left(30^{\circ} \mathrm{C} / 10 \mathrm{~Pa}\right)\end{array}$ \\
\hline Gęstość zaczynu $\left[\mathrm{kg} / \mathrm{m}^{3}\right]$ & 1820 & 1825 & 1830 & 1820 & 1825 & 1830 \\
\hline $\begin{array}{l}\text { Odstój wody z zaczynu mierzony pod } \\
\text { kątem } 90^{\circ}[\%]\end{array}$ & 0,5 & 0,0 & 0,0 & 0,5 & 0,0 & 0,0 \\
\hline Lepkość plastyczna zaczynu $[\mathrm{mPa} \cdot \mathrm{s}]$ & 126,0 & 138,0 & 153,0 & 124,5 & 136,5 & 148,5 \\
\hline Granica płynięcia zaczynu [Pa] & 3,8 & 11,5 & 20,1 & 2,6 & 10,3 & 20,4 \\
\hline Czas przejścia - TT (transition time) [minuty] & 46 & 20 & 9 & 58 & 28 & 11 \\
\hline Początek wiązania $(\mathrm{Pw})$ [godziny:minuty] & $4: 23$ & 4:04 & $3: 45$ & 5:06 & $4: 43$ & $4: 23$ \\
\hline Koniec wiązania (Kw) [godziny:minuty] & $5: 32$ & $5: 13$ & $4: 33$ & $6: 08$ & $5: 37$ & $4: 53$ \\
\hline Czas wiązania (Kw-Pw) [minuty] & 69 & 67 & 48 & 62 & 54 & 30 \\
\hline $\begin{array}{l}\text { Wytrzymałość na ściskanie kamienia cemento- } \\
\text { wego po } 48 \text { godzinach hydratacji [MPa] }\end{array}$ & 19,4 & 21,9 & 22,2 & 19,0 & 21,6 & 22,1 \\
\hline
\end{tabular}


Tabela 3. Składy zaczynów cementowych testowanych w temperaturze $60^{\circ} \mathrm{C}$ i pod ciśnieniem $25 \mathrm{MPa}$

Table 3. Compositions of cement slurries tested at $60^{\circ} \mathrm{C}$ and a pressure of $25 \mathrm{MPa}$

\begin{tabular}{|c|c|c|c|c|}
\hline $\begin{array}{c}\text { Symbol zaczynu, temperatura i ciśnienie / } \\
\text { Skladniki w [\%] bwoc }\end{array}$ & $\begin{array}{c}\text { Zaczyn G } \\
\left(60^{\circ} \mathrm{C} / 25 \mathrm{~Pa}\right)\end{array}$ & $\begin{array}{c}\text { Zaczyn H } \\
\left(60^{\circ} \mathrm{C} / 25 \mathrm{~Pa}\right)\end{array}$ & $\begin{array}{c}\text { Zaczyn J } \\
\left(60^{\circ} \mathrm{C} / 25 \mathrm{~Pa}\right)\end{array}$ & $\begin{array}{c}\text { Zaczyn K } \\
\left(60^{\circ} \mathrm{C} / 25 \mathrm{~Pa}\right)\end{array}$ \\
\hline Współczynnik w/c (woda wodociągowa) & 0,44 & 0,44 & 0,44 & 0,44 \\
\hline Nanotlenek glinu, $\mathrm{n}-\mathrm{Al}_{2} \mathrm{O}_{3}$ & - & 1 & 3 & 5 \\
\hline $\mathrm{KCl}^{* *}$ & 3,0 & 3,0 & 3,0 & 3,0 \\
\hline Dodatek odpieniający & 0,5 & 0,5 & 0,5 & 0,5 \\
\hline Dodatek upłynniający & 0,1 & 0,1 & 0,1 & 0,1 \\
\hline Opóźniacz czasu wiązania & 0,3 & 0,3 & 0,3 & 0,3 \\
\hline Cement wiertniczy G & 100 & 100 & 100 & 100 \\
\hline
\end{tabular}

Tabela 4. Parametry zaczynów i kamieni cementowych testowanych w temperaturze $60^{\circ} \mathrm{C}$ i pod ciśnieniem $25 \mathrm{MPa}$

Table 4. Parameters of cement slurries and sheaths tested at $60^{\circ} \mathrm{C}$ and a pressure of $25 \mathrm{MPa}$

\begin{tabular}{|c|c|c|c|c|}
\hline $\begin{array}{l}\text { Symbol zaczynu, temperatura i ciśnienie / } \\
\text { Oznaczany parametr }\end{array}$ & $\begin{array}{c}\text { Zaczyn G } \\
\left(60^{\circ} \mathrm{C} / 25 \mathrm{~Pa}\right)\end{array}$ & $\begin{array}{c}\text { Zaczyn H } \\
\left(60^{\circ} \mathrm{C} / 25 \mathrm{~Pa}\right)\end{array}$ & $\begin{array}{c}\text { Zaczyn J } \\
\left(60^{\circ} \mathrm{C} / 25 \mathrm{~Pa}\right)\end{array}$ & $\begin{array}{c}\text { Zaczyn K } \\
\left(60^{\circ} \mathrm{C} / 25 \mathrm{~Pa}\right)\end{array}$ \\
\hline Gęstość zaczynu $\left[\mathrm{kg} / \mathrm{m}^{3}\right]$ & 1900 & 1905 & 1910 & 1920 \\
\hline Odstój wody z zaczynu mierzony pod kątem $90^{\circ}$ [\%] & 0,3 & 0,0 & 0,0 & 0,0 \\
\hline Lepkość plastyczna zaczynu $[\mathrm{mPa} \cdot \mathrm{s}]$ & 87,0 & 117,0 & 151,5 & 172,5 \\
\hline Granica płynięcia zaczynu [Pa] & 3,4 & 4,3 & 5,5 & 6,0 \\
\hline $\begin{array}{l}\text { Czas uzyskania przez zaczyn konsystencji } 30 \mathrm{Bc} \text { w warunkach } \\
\text { HPHT [godziny:minuty] }\end{array}$ & $3: 51$ & $3: 32$ & $2: 58$ & $2: 35$ \\
\hline $\begin{array}{l}\text { Czas uzyskania przez zaczyn konsystencji } 100 \mathrm{Bc} \text { w warunkach } \\
\text { HPHT [godziny:minuty] }\end{array}$ & $5: 02$ & $4: 46$ & 4:03 & $3: 48$ \\
\hline $\begin{array}{l}\text { Wczesna wytrzymałość na ściskanie kamienia cementowego po } \\
48 \text { godzinach hydratacji - badanie na UCA [MPa] }\end{array}$ & 25,9 & 28,2 & 31,0 & 24,4 \\
\hline
\end{tabular}

Tabela 5. Zestawienie porowatości oraz rozkładu średnic porów dla stwardniałych zaczynów cementowych oznaczonych symbolami G, H, J oraz K po 28 dniach hydratacji

Table 5. Porosity and pore diameter distribution for set cement marked G, H, J and K after 28 days of hydration

\begin{tabular}{|l|c|c|c|c|}
\hline \multirow{2}{*}{ Oznaczenie próbki } & \multirow{2}{*}{$\begin{array}{c}\text { Porowatość ogólna } \\
\text { po 28 dniach [\%] }\end{array}$} & \multicolumn{3}{|c|}{$\begin{array}{c}\text { Udzial procentowy porów o danej średnicy } \\
\text { w stosunku do calkowitej ilości porów }\end{array}$} \\
\cline { 3 - 5 } & & $>\mathbf{1 0} \mathbf{0 0 0} \mathbf{~ n m}$ & $\mathbf{1 0} \mathbf{0 0 0}-\mathbf{1 0 0} \mathbf{~ n m}$ & $<\mathbf{1 0 0} \mathbf{~ n m}$ \\
\hline \hline Zaczyn $\mathbf{G}\left(60^{\circ} \mathrm{C} / 25 \mathrm{MPa}\right)$ & 31,7 & $3,8 \%$ & $4,6 \%$ & $91,6 \%$ \\
\hline Zaczyn $\mathbf{H}\left(60^{\circ} \mathrm{C} / 25 \mathrm{MPa}\right)$ & 27,4 & $1,9 \%$ & $2,0 \%$ & $96,1 \%$ \\
\hline Zaczyn $\mathbf{J}\left(60^{\circ} \mathrm{C} / 25 \mathrm{MPa}\right)$ & 26,9 & $1,5 \%$ & $1,8 \%$ & $96,7 \%$ \\
\hline Zaczyn $\mathbf{K}\left(60^{\circ} \mathrm{C} / 25 \mathrm{MPa}\right)$ & 28,5 & $2,8 \%$ & $3,9 \%$ & $93,3 \%$ \\
\hline
\end{tabular}

O niezwykle zwartej mikrostrukturze próbek zawierających $3 \% \mathrm{n}-\mathrm{Al}_{2} \mathrm{O}_{3}$ mogą ponadto świadczyć fotografie stwardniałych próbek zaczynów wykonane za pomocą mikroskopii skaningowej (SEM). Rysunki 11a i 11b (fotografie o powiększeniach odpowiednio 500- oraz 1300-krotnym) ukazują przeciętny obraz mikrostruktury zaczynu bazowego niezawierającego dodatku nanotlenku glinu. Na fotografiach można zaobserwować pory o dość dużych rozmiarach, które w przypadku połączenia się ze sobą mogą tworzyć kanaliki w stwardniałym zaczynie cementowym, wskutek czego po zacementowaniu może nastąpić ewentualny przepływ gazu w przestrzeni pierścieniowej w otworze wiertniczym. W wyniku zastosowania modyfikacji, w której użyte zostało 3\% nanotlenku glinu $\left(\mathrm{n}-\mathrm{Al}_{2} \mathrm{O}_{3}\right)$, struktura kamienia cementowego uległa znacznemu zagęszczeniu oraz nastąpiło wypełnienie porów przez nanocząsteczki (rys. 12a - pow. 500-krotne oraz $12 \mathrm{~b}$ - pow. 1300-krotne). Można zauważyć, że zmodyfikowana nanokomponentami matryca cementowa jest wyjątkowo zwarta i nie występują w niej obszary makroporów. Kamień cementowy zmodyfikowany $\mathrm{n}-\mathrm{Al}_{2} \mathrm{O}_{3}$ (składy oznaczone symbolami $\mathrm{H}$ oraz J) wykazuje zatem bardzo wysoką szczelność oraz obniżoną porowatość ogólną w stosunku do zaczynu bazowego. Kamień ten cechuje się również bardzo małą ilością porów kapilarnych (poniżej 2\%). 

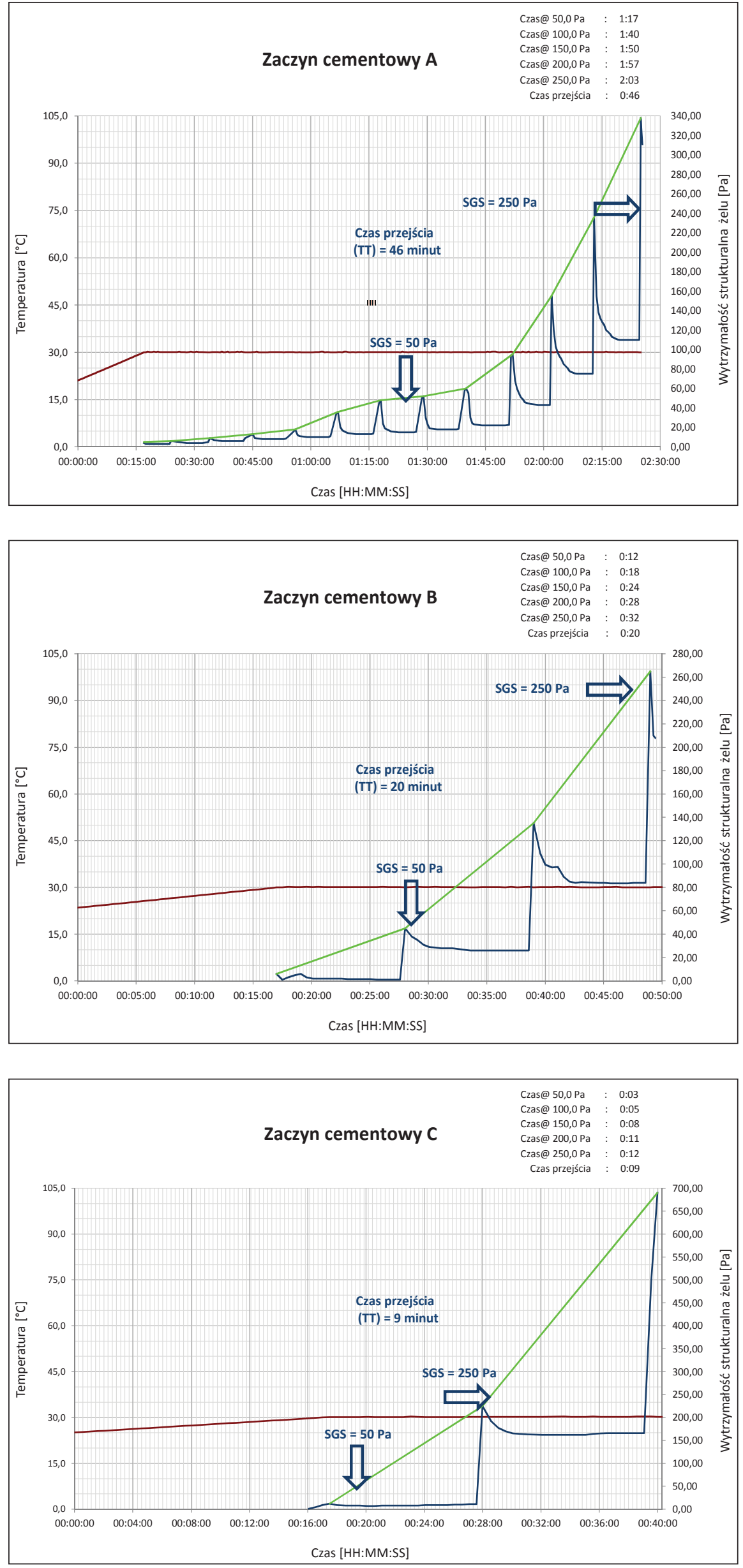

Legenda
Temperatura
Wytrzymałość strukturalna żelu
Wartość żelu

Rys. 2. Narastanie statycznej wytrzymałości strukturalnej dla zaczynu cementowego A (bez dodatku n- $\mathrm{Al}_{2} \mathrm{O}_{3}$ )

Fig. 2. Static gel strength development for cement slurry $\mathrm{A}$ (without $\mathrm{n}-\mathrm{Al}_{2} \mathrm{O}_{3}$ )

Rys. 3. Narastanie statycznej wytrzymałości strukturalnej dla zaczynu cementowego B $\left(1 \% \mathrm{n}-\mathrm{Al}_{2} \mathrm{O}_{3}\right)$

Fig. 3. Static gel strength development for cement slurry $\mathrm{B}\left(1 \% \mathrm{n}-\mathrm{Al}_{2} \mathrm{O}_{3}\right)$

Rys. 4. Narastanie statycznej wytrzymałości strukturalnej dla zaczynu cementowego $\mathrm{C}$ (z dodatkiem 3\% n- $\mathrm{Al}_{2} \mathrm{O}_{3}$ )

Fig. 4. Static gel strength development for cement slurry $\mathrm{C}\left(3 \% \mathrm{n}-\mathrm{Al}_{2} \mathrm{O}_{3}\right)$ 

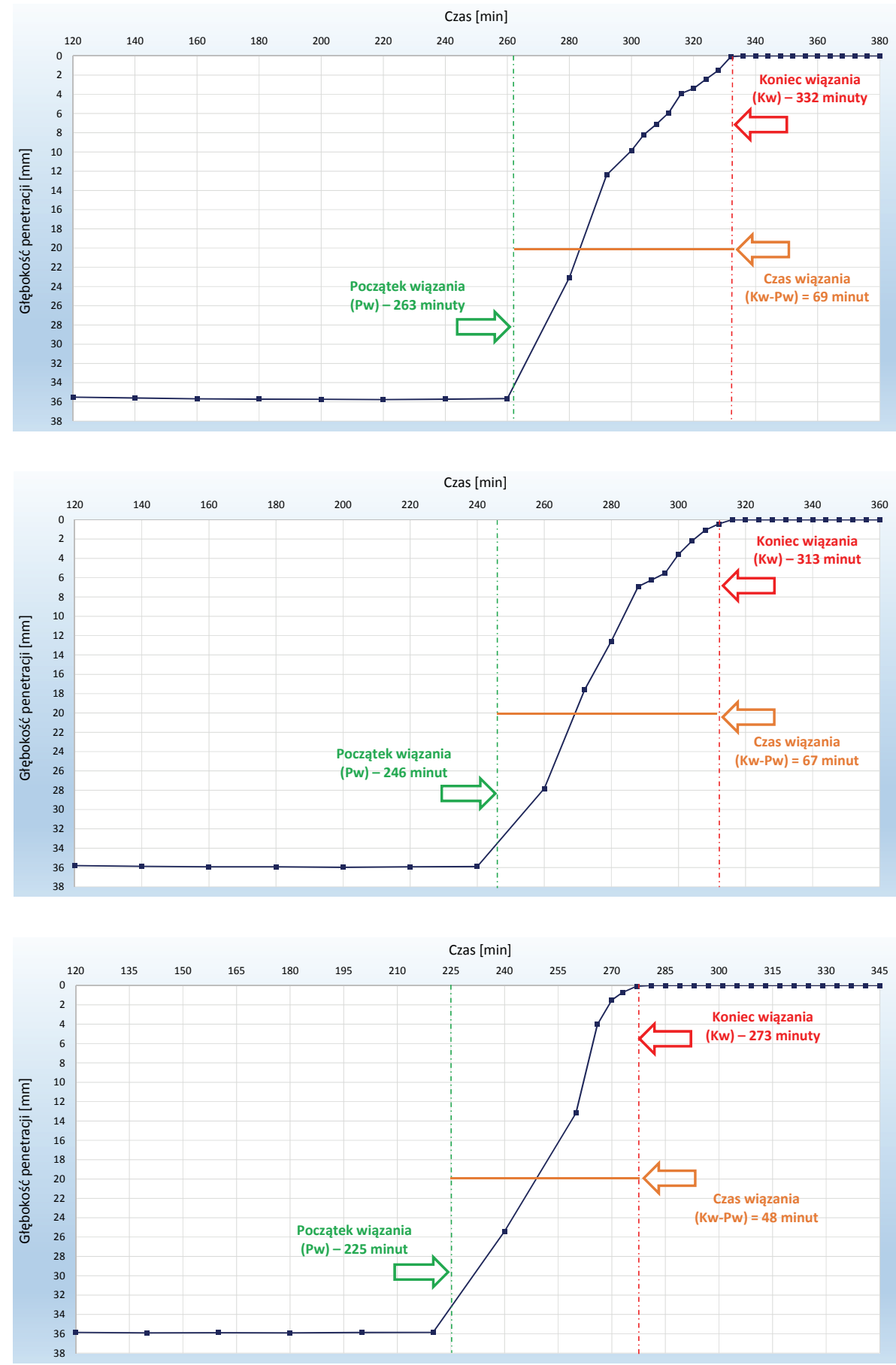

Rys. 5. Przebieg procesu wiązania dla zaczynu cementowego A (bez dodatku $\mathrm{n}-\mathrm{Al}_{2} \mathrm{O}_{3}$ )

Fig. 5. Setting time plot of cement slurry A (without $\mathrm{n}-\mathrm{Al}_{2} \mathrm{O}_{3}$ )

Rys. 6. Przebieg procesu wiązania dla zaczynu cementowego B $\left(1 \% \mathrm{n}-\mathrm{Al}_{2} \mathrm{O}_{3}\right)$

Fig. 6. Setting time plot of cement slurry $\mathrm{B}$ $\left(1 \% \mathrm{n}-\mathrm{Al}_{2} \mathrm{O}_{3}\right)$

Rys. 7. Przebieg procesu wiązania dla zaczynu cementowego C (z dodatkiem 3\% $\left.\mathrm{n}-\mathrm{Al}_{2} \mathrm{O}_{3}\right)$

Fig. 7. Setting time plot of cement slurry $\mathrm{C}$ $\left(3 \% \mathrm{n}-\mathrm{Al}_{2} \mathrm{O}_{3}\right)$

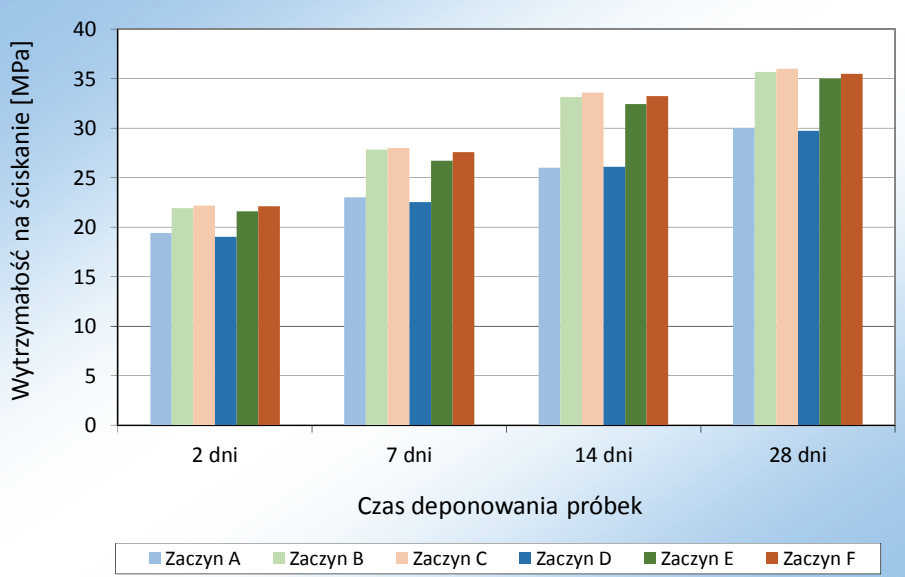

Rys. 8. Zmiany wytrzymałości na ściskanie dla próbek A, B, C, D, E oraz F po 2, 7, 14 i 28 dniach hydratacji

Fig. 8. Changes in compressive strength for samples A. B, C, $\mathrm{D}, \mathrm{E}$ and $\mathrm{F}$ after 2, 7, 14, and 28 days of hydration 


\section{NAFTA-GAZ}

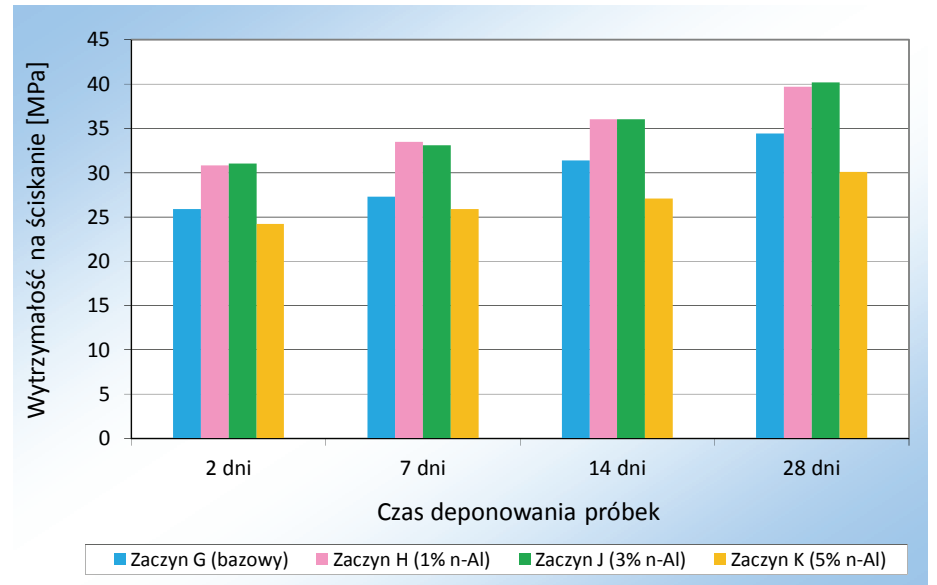

Rys. 9. Narastanie wczesnej wytrzymałości mechanicznej próbki J

Fig. 9. Development of early-age compressive strength of sample J

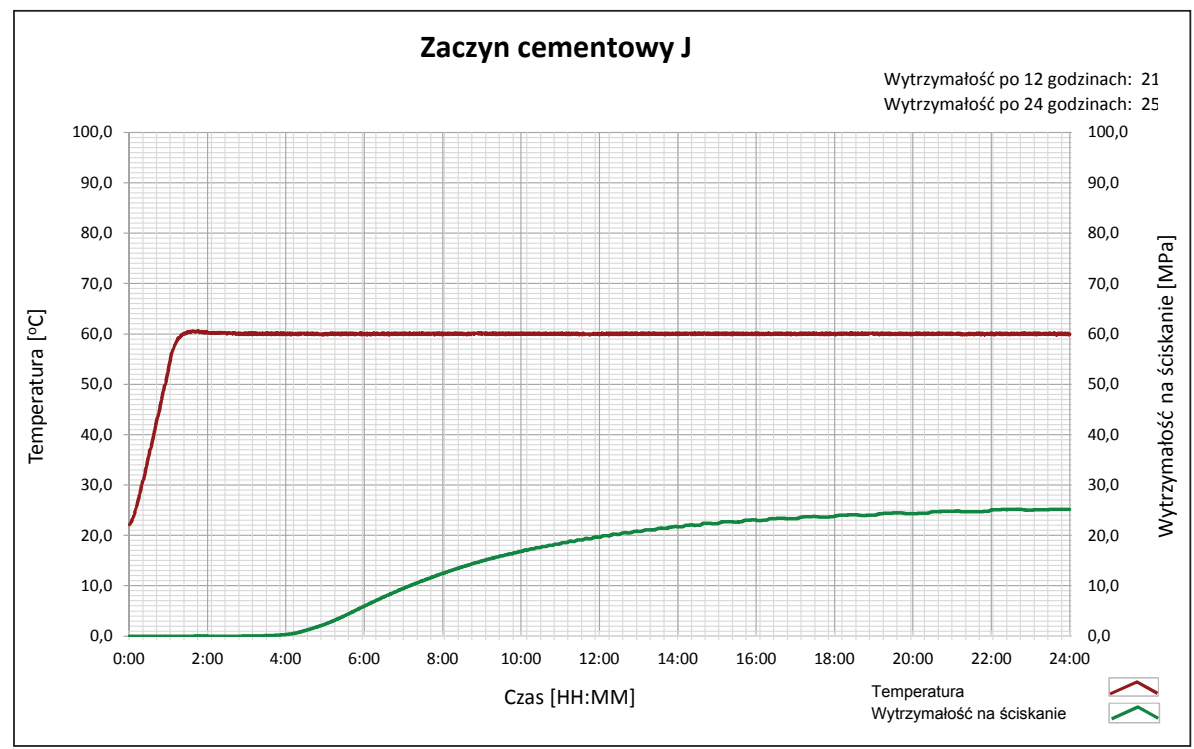

Rys. 10. Zmiany wytrzymałości na ściskanie dla próbek $\mathrm{G}, \mathrm{H}$, J oraz K po 2, 7, 14 i 28 dniach hydratacji

Fig. 10. Changes in compressive strength for samples $\mathrm{G}, \mathrm{H}, \mathrm{J}$ and $\mathrm{K}$ after 2, 7, 14, and 28 days of hydration

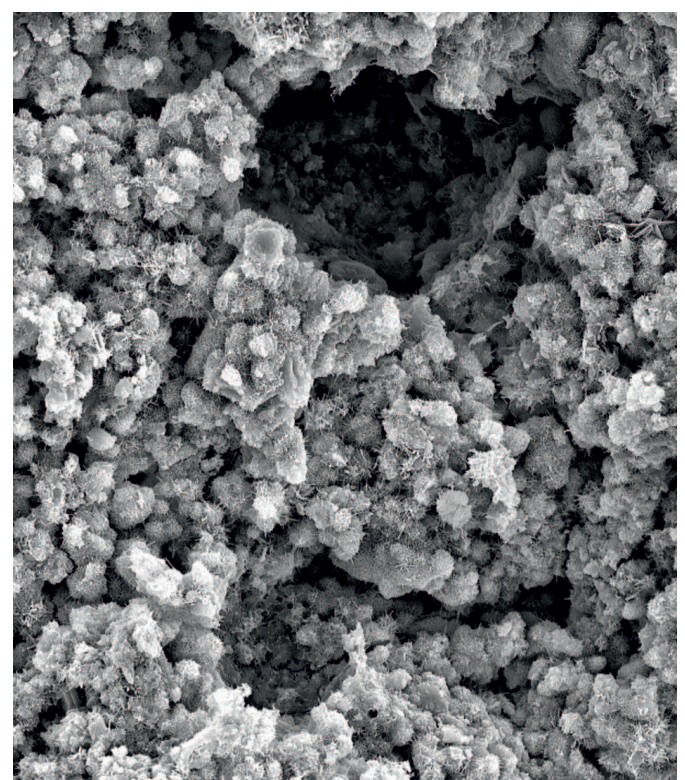

Rys. 11a. Przykładowa mikrostruktura zaczynu cementowego „konwencjonalnego” (bez dodatku nanokomponentów). Powiększenie 500-krotne

Fig. 11a. An example of microstructure of a "conventional" cement slurry (without the addition of nanocomponents). Magnification 500x

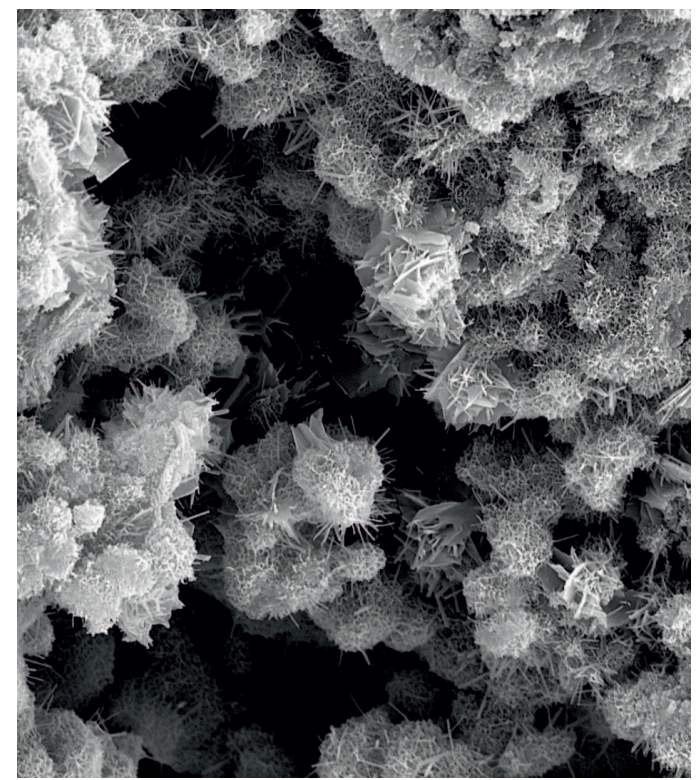

Rys. 11b. Przykładowa mikrostruktura zaczynu cementowego „konwencjonalnego” (bez dodatku nanokomponentów). Powiększenie 1300-krotne

Fig. 11b. An example of microstructure of a "conventional" cement slurry (without the addition of nanocomponents). Magnification 1300x 


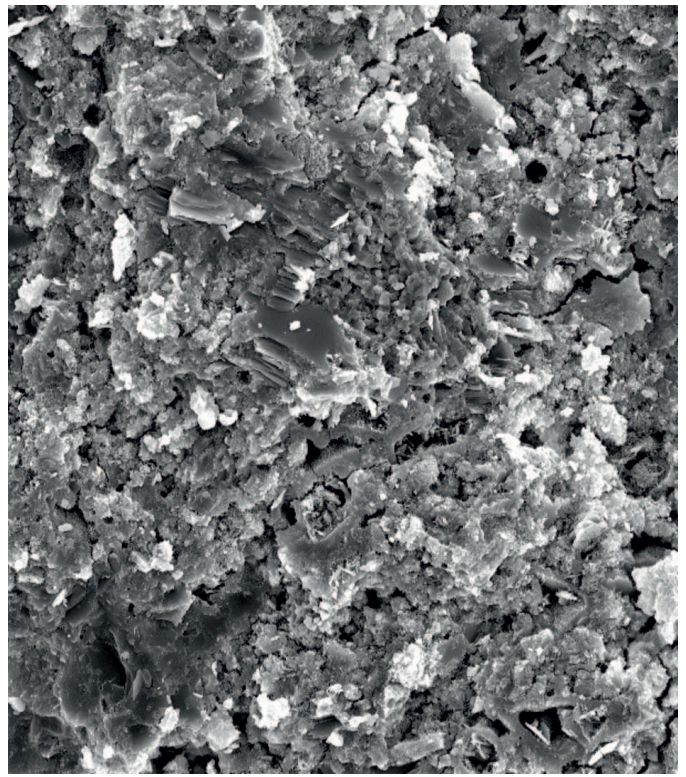

Rys. 12a. Przykładowa mikrostruktura zaczynu cementowego zawierającego 3\% n- $\mathrm{Al}_{2} \mathrm{O}_{3}$. Powiększenie 500-krotne

Fig. 12a. An example of microstructure of a cement slurry with $3 \%$ of $n-\mathrm{Al}_{2} \mathrm{O}_{3}$. Magnification 500x

\section{Podsumowanie}

Zaprezentowane $\mathrm{w}$ artykule zaczyny cementowe $\mathrm{z}$ dodatkiem nanocząsteczek glinu $\left(\mathrm{n}-\mathrm{Al}_{2} \mathrm{O}_{3}\right)$ charakteryzują się bardzo dobrymi parametrami technologicznymi i mogą być używane do uszczelniania rur okładzinowych w otworach wiertniczych:

- w początkowych interwałach, od kilkudziesięciu do kilkuset metrów (dla temperatury dennej około $30^{\circ} \mathrm{C}$ ) - jako receptury zapobiegające migracji gazu z płytko zalegających horyzontów;

- w głębszych interwałach, od około 1500 do około 2500 metrów (dla temperatury dennej ok. $60^{\circ} \mathrm{C}$ ) - jako receptury o podwyższonej wytrzymałości mechanicznej i niezwykle szczelnej i zbitej mikrostrukturze.

Po wykonaniu badań laboratoryjnych można stwierdzić, że:

a) w przypadku zaczynów badanych w temperaturze $30^{\circ} \mathrm{C}$ na bazie cementu portlandzkiego CEM I 42,5:

- najkorzystniejsze parametry technologiczne uzyskano dla próbek zawierających $1 \% \mathrm{n}-\mathrm{Al}_{2} \mathrm{O}_{3}$. Optymalny współczynnik wodno-cementowy dla takich zaczynów kształtował się na poziomie około 0,50 , a zaczyny posiadały gęstość około $1825 \mathrm{~kg} / \mathrm{m}^{3}$,

- najistotniejszymi cechami zaczynów było szybkie żelowanie oraz postępujące za nim procesy wiązania, które da się z powodzeniem regulować powszechnie stosowanymi dodatkami przyspieszającymi;

b) w przypadku zaczynów badanych w temperaturze $60^{\circ} \mathrm{C}$ na bazie cementu wiertniczego klasy .G":

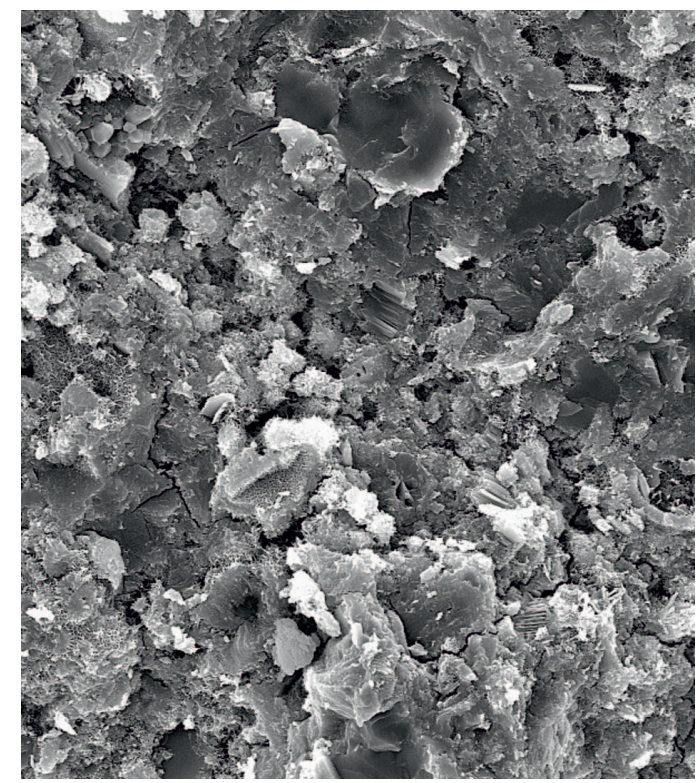

Rys. 12b. Przykładowa mikrostruktura zaczynu cementowego zawierającego $3 \% \mathrm{n}-\mathrm{Al}_{2} \mathrm{O}_{3}$. Powiększenie 1300-krotne

Fig. 12b. An example of microstructure of a cement slurry with $3 \%$ of $n-\mathrm{Al}_{2} \mathrm{O}_{3}$. Magnification $1300 \mathrm{x}$

- bardzo dobre parametry technologiczne uzyskano dla próbek zawierających $1 \% \mathrm{n}-\mathrm{Al}_{2} \mathrm{O}_{3}$ oraz $3 \% \mathrm{n}-\mathrm{Al}_{2} \mathrm{O}_{3}$. Optymalny współczynnik wodno-cementowy dla takich zaczynów kształtował się na poziomie około 0,44 , a zaczyny posiadały gęstość około $1905-1910 \mathrm{~kg} / \mathrm{m}^{3}$,

- najważniejszą zaletą zaczynów była wysoka wytrzymałość mechaniczna oraz zwarta i mało porowata mikrostruktura.

Dokonując ogólnej analizy uzyskanych wyników badań laboratoryjnych, można zauważyć, że komponent $\mathrm{n}-\mathrm{Al}_{2} \mathrm{O}_{3}$ powoduje wyraźną poprawę parametrów płynnego i stwardniałego zaczynu cementowego. Nanotlenek glinu redukuje odstój wody, czyli tzw. wolną wodę z zaczynów, co ma szczególne znaczenie w przypadku cementowania otworów kierunkowych. Wzrost stężenia nanotlenku glinu powoduje podwyższenie lepkości plastycznej oraz granicy płynięcia zaczynów cementowych, a także wyraźne skracanie czasu żelowania receptur (n-A12O3 działa również jako przyspieszacz początku i końca wiązania oraz powoduje skrócenie czasu gęstnienia zaczynów cementowych, co w pewnych przepadkach może wpływać niekorzystnie na parametry technologiczne zaczynu cementowego). Podobnie jak w przypadku zaczynów zawierających nanokrzemionkę (Rzepka i Kędzierski, 2019), również w zaczynach mających w składzie $n-\mathrm{Al}_{2} \mathrm{O}_{3}$ zaobserwowano podwyższone (w porównaniu do zaczynu bazowego) wartości wytrzymałości na ściskanie, wynikające ze szczelnego upakowania się w matrycy cementowej nanocząsteczek o bardzo małych rozmiarach. Mikrostruktura zaczynów z nanotlenkiem glinu jest zwarta i cechuje się niewielką 
porowatością, o czym świadczą fotografie wykonane pod mikroskopem skaningowym oraz testy przeprowadzone na porozymetrze. Porowatości próbek zawierających dodatek n- $\mathrm{Al}_{2} \mathrm{O}_{3}$ były znacznie niższe niż porowatości zaczynu bazowego. Próbki zawierające $1 \%$ oraz $3 \% \mathrm{n}-\mathrm{Al}_{2} \mathrm{O}_{3}$ posiadały bardzo niską (około 1,5\%) zawartość porów kapilarnych. Pory o najmniejszych rozmiarach (poniżej $100 \mathrm{~nm}$ ) stanowiły zdecydowaną większość (powyżej 96\%) ogólnej ilości porów występujących w matrycy cementowej. Dzięki zastosowaniu zaczynów zawierających $n-\mathrm{Al}_{2} \mathrm{O}_{3}$ zachodzi minimalne niebezpieczeństwo wytworzenia się ewentualnych kanalików dla przepływu mediów złożowych w płaszczu cementowym otworu wiertniczego.

Artykuł powstał na podstawie prac statutowych pt.: Zaczyny cementowe o krótkich czasach żelowania $i$ wiazania do uszczelniania plytkich otworów wiertniczych - praca INiG - PIB na zlecenie MNiSW; nr zlecenia: 0017/KW/2018, nr archiwalny: DK-41000017/2018, oraz Analiza wpływu dodatków nanocząsteczek na mikrostrukturę stwardniałych zaczynów cementowych - praca INiG - PIB na zlecenie MNiSW; nr zlecenia: 0041/KW/2016, nr archiwalny: DK-4100-0041/2016.

\section{Literatura}

De La Roij R.., Egyed C., Lips J.P., 2012. Nano-Engineered Oil Well Cement Improves Flexibility and Increases Compressive Strength: A Laboratory Study. Society of Petroleum Engineers. DOI: $10.2118 / 156501-M S$

Dębińska E., 2014. Wpływ nanokrzemionki na parametry mechaniczne kamienia cementowego. Nafta-Gaz, 4: 229-235.

Dębińska E., 2015. Niekonwencjonalne zaczyny cementowe z dodatkiem nanokrzemionki. Nafta-Gaz, 5: 290-300.

Dębińska E., Rzepka M., 2016. Nanocząsteczki - nowa droga w kształtowaniu parametrów świeżych i stwardniałych zaczynów cementowych. Nafta-Gaz, 12: 1084-1091. DOI: 10.18668/NG.2016.12.11.

Hadi H.A., Ameer H.A., 2017, Experimental Investigation of Nano Alumina and Nano Silica on Strength and Consistency of Oil Well Cement. Journal of Engineering, 23(12): 51-69.

Leon N., Massana J., Alonso F., Moragues A., Sanchez-Espinosa A., 2014. Effect of nano- $\mathrm{Si}_{2} \mathrm{O}$ and nano- $\mathrm{Al}_{2} \mathrm{O}_{3}$ on cement mortars for use in agriculture and livestock production. Biosystems Engineering, 123: 1-11. DOI: 10.1016/j.biosystemseng.2014.04.009.

Li H., Xiao H., Yuan J., Ou J., 2004. Microstructure of Cement Mortar with Nano-Particles. Composites Part B: Engineering, 35: 185-189. DOI: 10.1016/S1359-8368(03)00052-0.

Li Z., Wang H., He S., Lu Y., Wang M., 2006. Investigations on the preparation and mechanical properties of the nano-alumina reinforced cement composite. Materials Letters, 60(3): 356-359. DOI: 10.1016/j.matlet.2005.08.061.

Nazari A., Riahi S., 2011. $\mathrm{Al}_{2} \mathrm{O}_{3}$ nanoparticles in concrete and different curing media. Energy and Buildings, 43: 1480-1488. DOI:10.1016/j.enbuild.2011.02.018.

Patil R., Deshpande A., 2012. Use of Nanomaterials in Cementing Applications. Society of Petroleum Engineers. DOI: 10.2118/155607-MS.

Rzepka M., Kędzierski M., 2019. Zaczyny cementowe z dodatkiem nanokomponentów do uszczelniania kolumn rur okładzinowych w otworach wiertniczych o głębokości końcowej około 1000-2000 metrów. Nafta-Gaz, 11: 674-682. DOI: 10.18668/NG.2019.11.02.

Rzepka M., Kremieniewski M., Kędzierski M., 2019. Cement slurries for sealing casing in boreholes with increased risk of gas migration. Nafta-Gaz, 9: 562-570. DOI: 10.18668/NG.2019.09.05.

Santra A., Boul P.J., Pang X., 2012. Influence of Nanomaterials in Oilwell Cement Hydration and Mechanical Properties. Society of Petroleum Engineers. DOI: 10.2118/156937-MS.

Uliasz M., Zima G., Błaż S., Jasiński B., 2015. Ocena właściwości cieczy wiertniczych w aspekcie zapobiegania migracji gazu w otworach na przedgórzu Karpat. Nafta-Gaz, 1: 11-17.

Wilk K., Kasza P., Czupski M., 2014. Zastosowanie nanocieczy jako dodatków wspomagających proces wypierania ropy naftowej. Nafta-Gaz, 1: 14-20.

\section{Akty prawne i normatywne}

PN-EN ISO 10426-1:2009 Przemyst naftowy i gazowniczy - Cementy i materialy do cementowania otworów - Czesść 1: Specyfikacja.

PN-EN ISO 10426-2:2003 Przemyst naftowy i gazowniczy - Cementy $i$ materiały do cementowania otworów wiertniczych-Czesśc 2: Badania cementów wiertniczych.

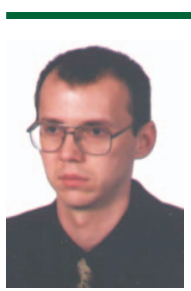

Dr inż. Marcin RZEPKA

Kierownik Laboratorium Zaczynów Uszczelniających w Zakładzie Technologii Wiercenia

Instytut Nafty i Gazu - Państwowy Instytut Badawczy ul. Lubicz $25 \mathrm{~A}$

31-503 Kraków

E-mail: marcin.rzepka@inig.pl

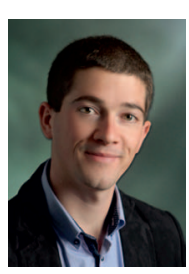

Mgr inż. Miłosz KĘDZIERSKI

Specjalista inżynieryjno-techniczny w Zakładzie Technologii Wiercenia

Instytut Nafty i Gazu - Państwowy Instytut Badawczy ul. Lubicz 25 A

31-503 Kraków

E-mail: milosz.kedzierski@inig.pl 